\title{
Working Capital Management and Its Impact on Firm's Financial Performance
}

\author{
U Rohini $^{1}$ | K Malarkodi ${ }^{1}$ | Dr. P Vanitha ${ }^{1}$ \\ ${ }^{1}$ Department of Management, M.Kumarasamy College of Engineering
}

\section{To Cite this Article}

U Rohini, K Malarkodi and Dr. P Vanitha, "Working Capital Management and Its Impact on Firm's Financial Performance”, International Journal for Modern Trends in Science and Technology, 6(8): 10-17, 2020.

\section{Article Info}

Received on 02-June-2020, Revised on 26-June-2020, Accepted on 23-July-2020, Published on 28-July-2020.

\section{ABSTRACT}

Managing working capital is an important metric for all businesses, regardless of their size and it is a signal of a company's operating liquidity. The purpose of the study is to maximize the productivity and profit in employment of capital for the smooth and rapid flow of fund is maintained and the efficiency working capital or profitability is enhanced.To answer the research question the study is setupwith Etexproinde.To test the hypothesis ratio analysis, working capital turnover, accounts receivable was applied. The study attempt maximizes the productivity and profits in the employment of capital.

Keywords: Working Capital Management, Financial Management, Financial Performance.

\section{INTRODUCTION}

Working capital management is very important because it is responsible for the liquidity and profitability of a company. It deals with current assets and current liabilities. The half of the total asset of the manufacturing company is current liabilities. Level of current assets helps for a easy result in a firms realizing a substandard return on assets, however firms with low current assets suffer shortages and difficulties for maintaining smooth operations and it ensures a company has enough cash flow that commit to meet its short term debt and its operating expenses.

A firm should maintain a balance between liquidity and profitability while conducting its regular operations. Amanagerial accounting strategy mainly focusing on both current assets and current liabilities. Simultaneous competitive business demands the efficient use of resource that underscores the importance of the working capital management. It is largely accepted that the profitability that determine the manner in which its working capital is managed the inadequate management of working capital not only reduce profitability and it leads to financial crisis in an organization.

\section{REVIEW OF LITERATURE}

Srinivasan (2001)ㅇsuggested in his study that the opportunity for using by predicts molasses, which will be available in increasing quantities', for producing industrial and potable alcohol, alcohol-based chemicals and ethanol should be fully utilized. There is also scope for adopting co-generating system on ambitious lines for generating power and producing steam with the use of bagasse in high pressure boilers'. Any surplus power can be sold to Tamil Nadu Electricity Board Grids at price advantage to both parties. These measures can help in reducing all manufacturing costs noticeably. 
Jadhaw(2001)told that approximately 70 percent of total world sugar production is consumed domestically in the countries of origin and about 25 percent is exported to other countries. It has been found form the study that the cost reduction is a continuous process of follow up. It needs evaluation, redesigning and re-evaluation. It is difficult to suggest "Universal Cost Reduction Techniques". To achieve cost reduction, it is necessary to follow the below mentioned steps:

1. Establishing our own standards.

2. Measuring performance against these standards and

3. Corrective deviation from standards.

It is also pointed out that the trust areas for cost reduction are improvements of efficiency and productivity along with reducing wastage of man hour materials and energy.

Pokharkar, kasar and shinde (2001)10have pointed out that basic objectives of the study has been to examine low productivity of sugarcane and profitability for different planting types in different recovery zones in Maharashtra. It has been concluded that there is a need to popularize the improved crop production technology among the sugarcane growers. It will ensure reduction in a cost of cultivation on one hand and maintain the productivity of sugarcane. The inputinfrastructure has to be properly developed to that crucial would be available to the growers in time to improve productivity.

Samar K. data (2001)11 computed and presented the growth rates of production and yield of sugarcane in this study, based on the source from Ministry of Agriculture, Government of India. Agriculture statistics at a glance, 2001. It has been found that the compound growth rate of production of sugarcane was only 2.70 and yield of sugarcane was only 0.82 during 1991-92 to 2000-01.

Bhattacharyya (2002)12discussed in his study, the negative export growth of sugar and molasses during 1995-96 to 1999-2000. It showed that it was 151.62 in 1995-96 in 1996-97, 68.68 in 1997-98, 5.81 in 1998-99 and 8.74 in 1999-2000. However, during 1999-2000, more than 70 percent of India agriculture exports have shown positive growth trend, while only 27 percent of agro exports (including sugar and molasses), and have shown a negative trend.

It is established by many empirical studies that the performance of firms can be prejudiced by many factors, one of which is working capital management. Working capital is observed as a measurement of both firms' liquidity and effectiveness.

In the world, many observed researches have been conducted in order to study the impact of working capital management on firm's financial performance. Most of the trainingsdetermined that working capital management expressively influences firm's profitability. However, the specific relationship between the two factors differentallowing to countries and markets.

The influence of working capital management on firm performance was encouraging in a number of studies. One of them is Asaduzzaman and Chowdhury (2014) in Bangladesh, an empirical study which was constructed upon the data from Bangladeshi Textiles firms. The authors found aimportant relationship between working capital management and profitability, using four dealings, Days of Inventory Outstanding (DIO), Days of Sales Outstanding (DSO), Cash Conversion Cycle (CCC), and Days of Payables Outstanding (DPO) to signify working capital management. While DPO exhibited a negative impact on profitability, the rest specified a positive correlation with firms' profitability. Another experimental research from Nigeria, Imeokparia (2015) has also found a confident relation between working capital management and firms' presentation. In addition, Akoto et al. (2013) had inspected the impact by using the data from Ghanaian companies, and the results advocated that working capital management (as measured by CCC) positively prejudiced firms' profitability as measured by net operating profits.

On the other hand, many researches provision the traditional belief of a undesirable relationship between working capital management and firms' performance; that is increasing working capital investment by floatingquantity of current assets in total assets would harmfully affect the profitability of firms. Using the same four processes of working capital management as the Asaduzzaman and Chowdhury (2014), Javid and Zita (2014) found aundesirable relationship between working capital management and profitability. Similarly, Padachi (2006), studying small-scale manufacturing enterprises in Mauritius for the period 1998-2003, presented that CCC is harmfully related to firm performance (as represented by ROA), and that high level of investment in inventories and account receivables is connected with low profitability. Raheman and Nasr (2007) in Pakistan, 
Garcia-Teruel and Solano (2007) in Spain and Kaddumi and Ramadan (2012) in Jordan all came to the conclusion that managers can produce more value by shortening CCC.

Develops the suggestion between present resources and present debts. Routinely, high existing extent is believed to be ansuggestion of cash related quality. It is the symbol of the organization's capability to quickly encounter its temporary debts. (Ftc 2008) Sets up ansuggestion between expedient assets and prevailing debts. Anbenefit is fluid in case it can be changed over into money instantly fast deprived of gone regard. Cash is the maximum liquid asset (Ftc, 2008). The amount of times stock renewed in a year. It is an reminder between typical stock at cost and cost of goods sold (Shim \&:Siegal, 1998). In this study financial performance measured finished the profitability of firm. Advantage is undisputable get from a business operation in the wake of subtracting for all expenses. The word advantage in aoverall sense got from the word "profectus" plans to advancement. Advantage is designated in two obvious highways, one is for bookkeeping and alternative one for monetary issues, and here just bookkeeping description is taken (Moffatt, 2002). Measuring productivity stays the same as measuring the achievement of a business. A wage proclamation demonstrates a breakdown of salary and costs amongst the business year. One measure of an organization's productivity is the profit proportion. Gainfulness scopes investigate the budgetary strength of a business. A gainfulness quantity takes a gander at how benefit was received in connection of deals, complement up to resources and total assets. In this study profitability of a firm is to be unrushed through the following ratios. Effectiveness is studied as the expenses and costs, and it is poor down nosily with resources to perceive how dangerous an affiliation is in distribution central focuses for make transactions and as time goes on benefits. The term return in the ROA degree when in uncertainty infers a net favourite standpoint or net remuneration, the measure of benefit from deals after all costs, costs and expenses. The more resources an affiliation has amassed, the more courses of achievement and possibly more preferences the affiliation may make. As economies of scale help chop down expenses and increase edges, return may make at a speedier rate than resources, at long last evolvingbenefit for resources. ROE is arange that stresses an association's reverence holders.since it gages their capability of picking up return on their esteem theories. ROE may augment absolutely with no esteem development when it can fundamentally benefit by a higher return helped by a greater asset base. As an association accumulates its favorable position evaluate and makes better return with higher edges, esteem holders can hold an awesome piece of a landing enhancement when additional assets are the result of commitment use. The gross net income looks of ainvention vended as a level of offers. It shows the financial health of an organization. Gross profit margin is aalteration between the cost of goods sold and revenue of a firm. Operating expenses are not a share of gross profit margin. While running an indispensable productivity range calculation net overall revenue is the as often as imaginable an edge extent used. The net income designates the how much a firm produced after abstracting all costs including expenses.

\section{RESEARCH METHODOLOGY}

\subsection{RESEARCH DESIGN}

The evaluation of the study is based on the secondary data collected from the annual reports , journals and magazines. The analysis drawn and recommendations made are based on the facts , graphs and diagrams which are given to represent statistical data of the study .

\subsection{METHOD OF DATA COLLECTION PRIMARY DATA:}

Primary data is first time (directly) collected data. SECONDARY DATA :

The information is already collected from following:

4. Company's annual report .

5. Company's websites.

6. Manual.

\subsection{TOOLS FOR DATA ANALYSIS}

$>$ Radio analysis

$>$ Accounts Receivable

$>$ Working Capital Turnover

\section{RATIO ANALYSIS}

Ratio analysis is a widely-used tool of financial analysis. It is defined as the systematic use of ration to interpret the financial statements so that the strengths and weaknesses of the firm as well as its historical performance and current financial condition can be determined. Ratio analysis is a powerful tool of financial analysis .

$>$ Current ratio

$>$ Quick ratio

$>$ Inventory turnover ratio 
$>$ Fixed asset turnover ratio

$>$ Equity ratio.

\section{Current Ratio :}

The current ratio measures the ability of the firm to meet its current liabilities, current assets gets converted into cash during the operating cycle of the firm and providesthe funds needed to pay current liabilities. So higher the current ratio, greater the short term solvency Current ratio =Current assets / currents liabilities . Current assets include cash, current investment,debtors, inventories, loans and advances and prepaid expense. Current liabilities include installments of loans.

\section{Quick Ratio :}

Quick assets are defined as current assets excluding inventories. Quick are also called as acid test ratio. It is based on those current assets which are highly liquid . Quick ratio =Quick assets / current liabilities.

\section{Inventory Turnover Ratio:}

These ratios measure how fast the inventory is moving through the firm and generating the sales. Inventory turnover reflects the efficency of inventory management. The higher the ratio is more efficient the management of inventories Inventory turnover ratio $=$ Cost of goods sold / average inventory.

\section{Fixed asset turnover ratio:}

Fixed Asset Turnover (FAT) is an efficiency ratio that indicates how well or efficiently a business uses fixed assets to generate sales. This ratio divides net sales by net fixed assets, calculated over an annual period. The net fixed assets include the amount of property, plant, and equipment, less the accumulated depreciation. Generally, a higher fixed asset ratio implies more effective utilization of investments in fixed assets to generate revenue. This ratio is often analyzed alongside leverage and profitability ratios.

\section{Equity ratio:}

The equity ratio is an investment leverage or solvency ratio that measures the amount of assets that are financed by owners' investments by comparing the total equity in the company to the total assets. The equity ratio highlights two important financial concepts of a solvent and sustainable business. The first component shows how much of the total company assets are owned outright by the investors. In other words, after all of the liabilities are paid off, the investors will end up with the remaining assets.
The second component inversely shows how leveraged the company is with debt.

\section{ACCOUNTS RECEIVABLE}

Accounts receivable (AR) is the balance of money due to a firm for goods or services delivered or used but not yet paid for by customers. Accounts receivables are listed on the balance sheet as a current asset. AR is any amount of money owed by customers for purchases made on credit.

\section{WORKING CAPITAL TURNOVER}

Working capital turnover is a ratio that measures how efficiently a company is using its working capital to support a given level of sales. Also referred to as net sales to working capital, work capital turnover shows the relationship between the funds used to finance a company's operations and the revenues a company generates as a result.

Working Capital Turnover Ratio Formula

$$
\begin{aligned}
& \text { Working capital } \\
& \text { turnover ratio }
\end{aligned}=\frac{\text { Revenue }}{\text { Working capital }}
$$

\section{Gross Ratio}

Gross Profit Ratio is a profitability ratio that shows the relationship between gross profit and total net sales revenue. It is a popular tool to evaluate the operational performance of the business. The ratio is computed by dividing the gross profit figure by net sales

\begin{tabular}{|c|c|}
\hline $\begin{array}{llll} & \text { e } & \text { a } & r\end{array}$ & Ratio \\
\hline $2016-2017$ & 0.141 \\
\hline $2017-2018$ & 0.106 \\
\hline $2018-2019$ & 0.09 \\
\hline
\end{tabular}

\section{Gross Ratio}

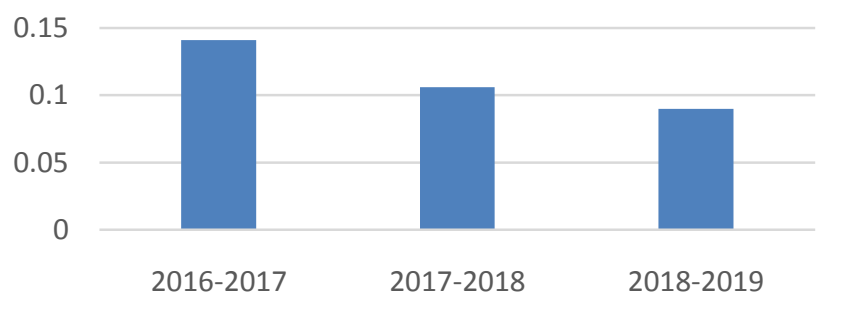

\section{Interpretation}

The above table shows the gross ratio for the period of three years. It was 0.141 in the year of 2016-2017 and it is decreased in the value of0.106 in the next year of 2017-2018 and continuous in the year of 2018-2019 gross profit ratio decreased. It may indicate decrease in the selling price of goods, without any decrease in the cost of goods sold. 


\section{Net Profit Ratio}

Profit margin,net margin,net profit margin or net profit is a measure of profitability .It is calculated by finding the net profit as percentage of the revenue

\begin{tabular}{|c|c|}
\hline 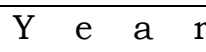 & Ratio \\
\hline $2016-2017$ & 0.05 \\
\hline $2017-2018$ & 0.01 \\
\hline $2018-2019$ & 0.01 \\
\hline
\end{tabular}

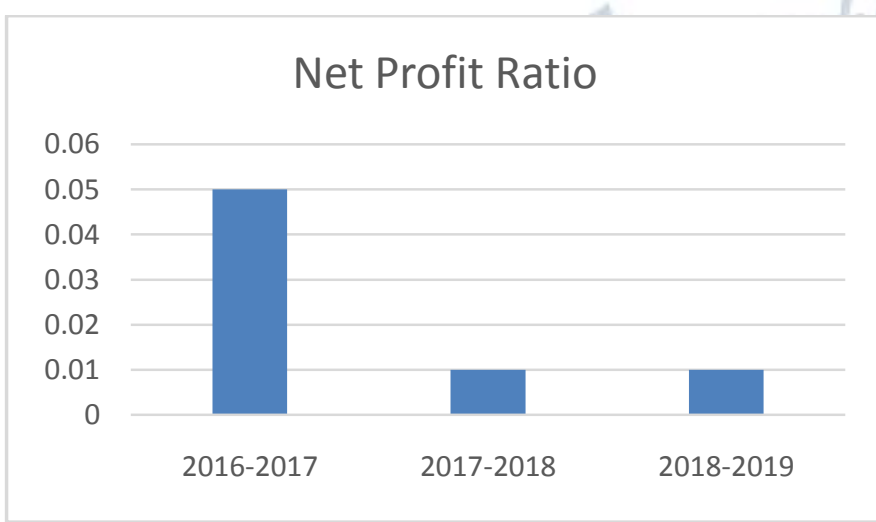

\section{Interpretation}

The above table shows the net profit ratio for the period of three years. It was 0.05 in the year of 2016-2017 and it is decreased in the next year to 0.01 during the year of 2017-2018 and next year the value remain same 0.01 in the year of 2018-2019 and the current year indicates the decline in performance and profitability levels of the company.

\section{Working Capital Turnover Ratio}

The Working Capital Turnover Ratio measures how well a company is utilizing its working capital to support a given level of sales .A high turnover ratio indicates that management is being extremely efficient in using a firms short term assets and liabilities of support sales

\begin{tabular}{|c|c|}
\hline $\begin{array}{llll}\mathrm{Y} & \mathrm{e} & \mathrm{a}\end{array}$ & Ratio \\
\hline $2016-2017$ & 8.9 \\
\hline $2017-2018$ & 11.62 \\
\hline $2018-2019$ & 3.9 \\
\hline
\end{tabular}

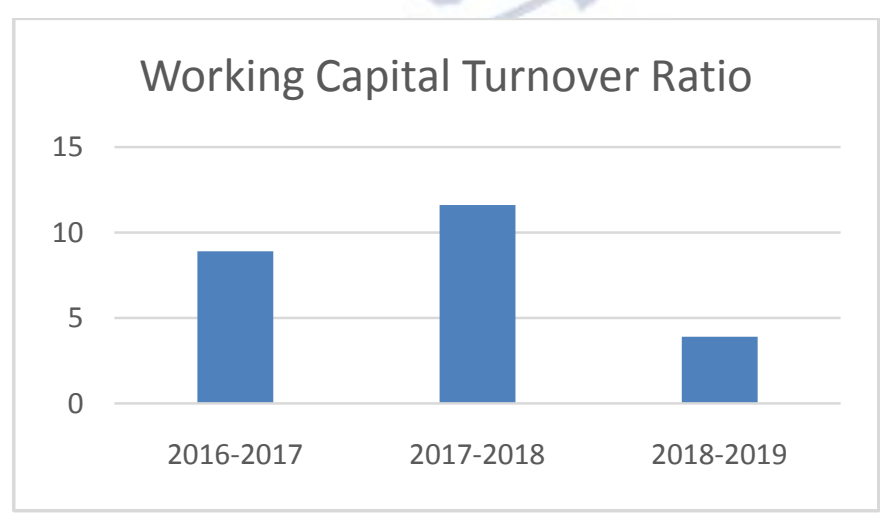

\section{Interpretation}

The above table shows the working capital turnover ratio for the period of three years. It was 8.9 in the year of 2016-2017 and it is increased in the next year to 11.62 during the year of 2017-2018. A high turnover ratio shows management is being very efficient in using a company short term assets and liabilities for the supporting sales. In 2018-2019 the ratio decreased to 3.9 and the decrease in the turnover ratio indicates inefficient utilization of working capital during the period.

\section{Current Ratio}

The Current Ratio is a liquidity ratio that measures whether a firm has enough resources to meet its short term obligations.It compares a firms current assets to its current liabilities.It is a indication of a firms liquidity

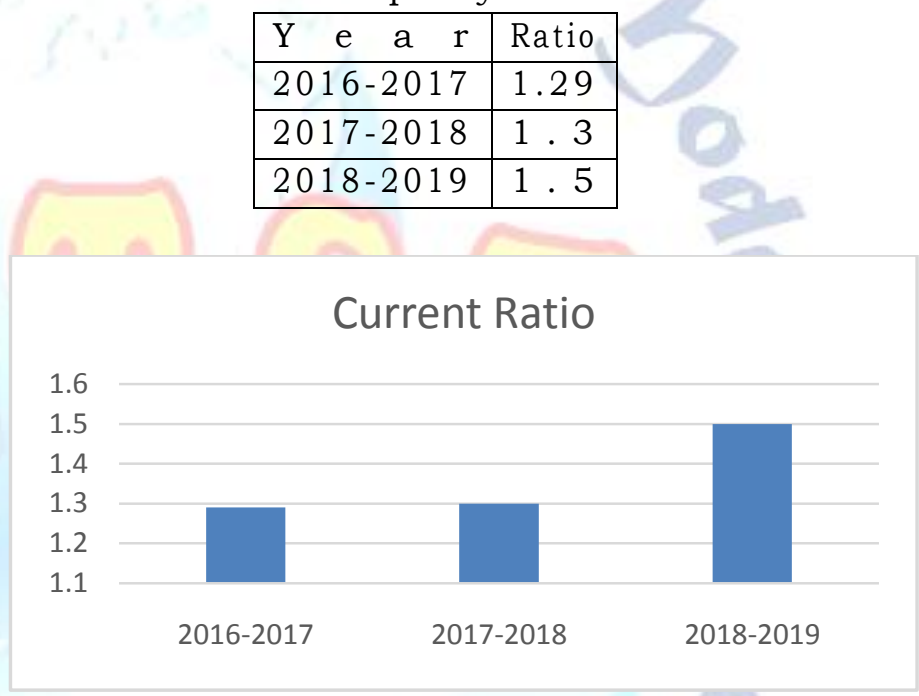

\section{Interpretation}

The above table shows the current ratio for the period of three years. It was 1.29 in the year of 2016-2017 and it is decreased in the next year to 1.3 during the year of 2017-2018. A increase in the current ratio indicates a company is growing into its capacity. In 2018-2019 the ratio increased to 1.5 its shows that current ratio of a company is able to meet its short term obligations.

\section{Current Asset Turnover Ratio}

Current Asset Turnover Ratio current indicates that the current assets are turned over in the form of sales more than number of times. A high Current Assets Turnover Ratio indicates the capability of the organization to achieve maximum sales with the minimum investment in current assets

\begin{tabular}{|c|c|}
\hline $\begin{array}{llll} & \text { e } & \text { a } & \text { r }\end{array}$ & Ratio \\
\hline $2016-2017$ & 2 \\
\hline $2017-2018$ & 3.06 \\
\hline $2018-2019$ & 3.86 \\
\hline
\end{tabular}




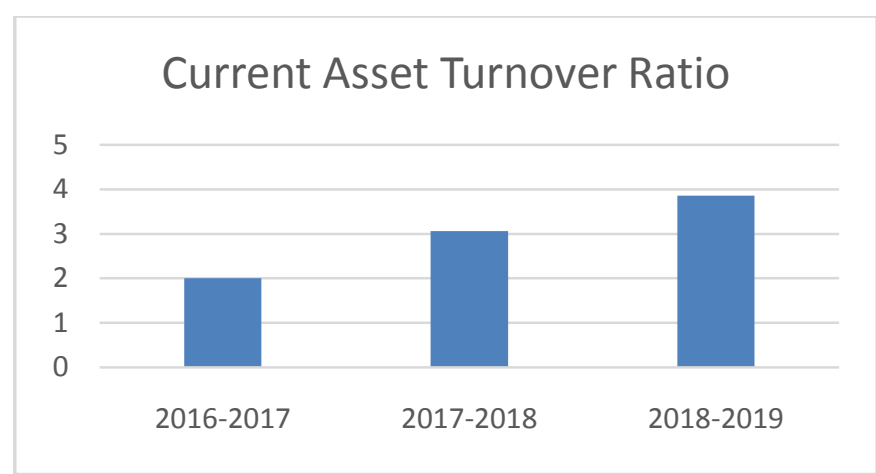

\section{Interpretation}

The above table shows the current asset turnover ratio for the period of three years. It was 2 in the year of 2016-2017 and it is increased in the next year to 3.06 during the year of 2017-2018. A high current assets turnover ratio indicates the capability of the organization to achieve maximum sales with the minimum investment in current assets. In 2018-2019 the ratio increased to 3.86 its indicates a more efficient use of assets.

\section{Fixed Asset Turnover Ratio}

Fixed Asset Turnover is the ratio of sales to the value of fixed assets. It indicates how well the business is using its fixed assets to generate sales

\begin{tabular}{|c|c|}
\hline $\begin{array}{llll} & \text { e } & \text { a } & \text { r }\end{array}$ & Ratio \\
\hline $2016-2017$ & 39.38 \\
\hline $2017-2018$ & 82.7 \\
\hline $2018-2019$ & 118.28 \\
\hline
\end{tabular}

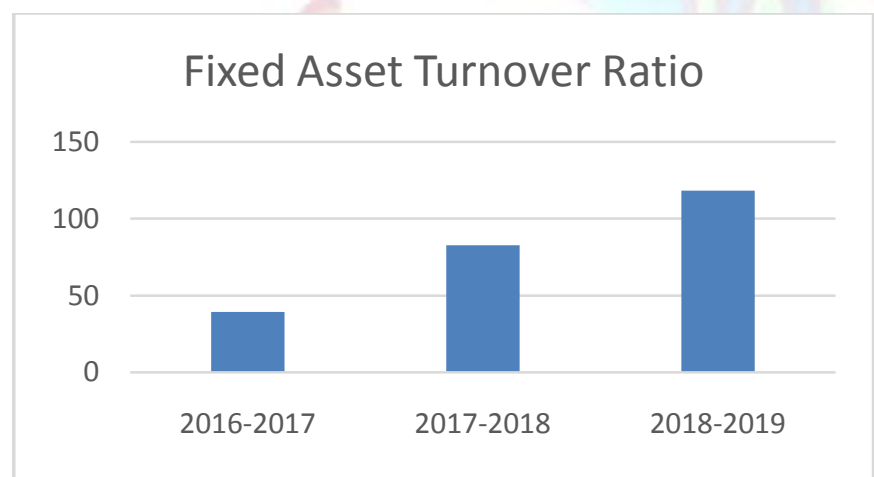

\section{Interpretation}

The above table shows the fixed asset turnover ratio for the period of three years. It was 39.38 in the year of 2016-2017 and it is increased in the next year to 82.7 during the year of 2017-2018. A high fixed asset turnover ratio indicates the firm effectively and efficiently uses its assets to generate revenues. In 2018-2019 the ratio increased to 3.86 its indicates the company is efficiently employ its assets to generate sales.

\section{Stock to W.C Ratio}

Inventory to working capital ratio is defined as a method to show what portion of a companys inventories is financed from its available cash.This is essential to businesses which hold inventory and survive on cash supplies

\begin{tabular}{|c|c|}
\hline $\begin{array}{llll} & \text { e } & \text { a } & \text { r }\end{array}$ & Ratio \\
\hline $2016-2017$ & 0.45 \\
\hline $2017-2018$ & 1.93 \\
\hline $2018-2019$ & 0.59 \\
\hline
\end{tabular}

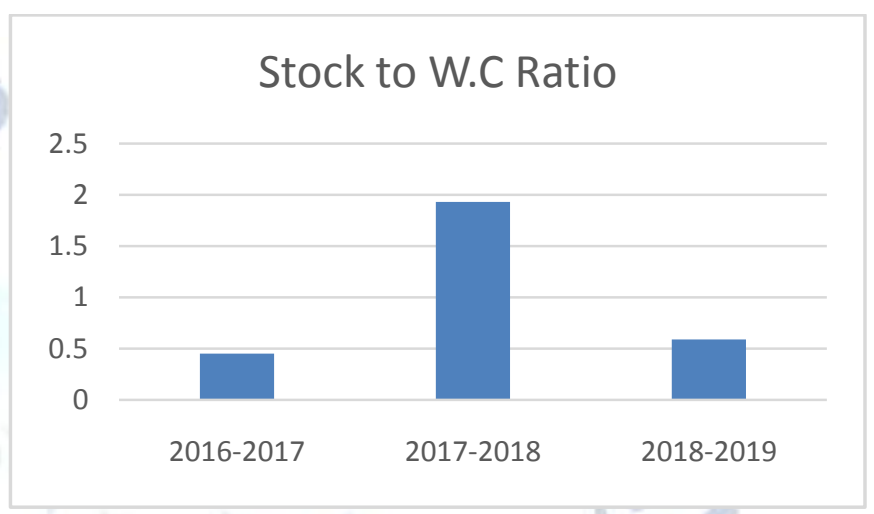

\section{Interpretation}

The above table shows the stock to working capital ratio for the period of three years. It was 0.45 in the year of 2016-2017 and it is increased in the next year to 1.93 during the year of 2017-2018. In the year of 2018-2019 the ratio is decreased to 0.59 and it indicates disability of a company to raise additional cash from working capital.

\section{Current Ratio to W.C Ratio}

The working capital ratio also caleed the current ratio, is a liquidity ratio that measures a firms ability to pay off its current liabilities with current assets. The working capital ratio transforms the working capital calculation into a comparison between current assets and current liabilities

\begin{tabular}{|c|c|}
\hline $\begin{array}{llll} & \text { e } & \text { a } & \text { r }\end{array}$ & Ratio \\
\hline $2016-2017$ & 4.44 \\
\hline $2017-2018$ & 3.78 \\
\hline $2018-2019$ & 1.03 \\
\hline
\end{tabular}

\section{Current Ratio to W.C Ratio}

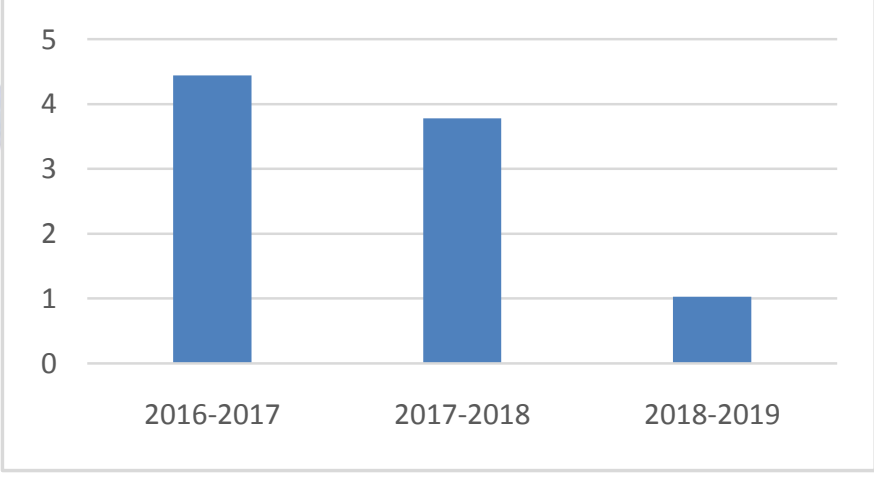




\section{Interpretation}

The above table shows the current ratio to working capital ratio for the period of three years. it was 4.44 in the year of 2016-2017 and its rapidly decreased in the next year to 3.78 during the year of 2017-2018. In the year of 2018-2019 the ratio is decreased to 1.03 and it indicates exceed liabilities and generally the higher the ratio and it will be better of the company.

\section{Trend Analysis on Sales}

Sales trend analysis is the review of historical revenue results to detect patterns. Sales trend analysis is a useful budgeting and financial analysis method that can indicate the onset of changes in the near term revenue growth rates of a business

\begin{tabular}{|c|c|}
\hline $\begin{array}{llll} & \mathrm{e} & \mathrm{a} & \mathrm{r}\end{array}$ & Ratio \\
\hline $2016-2017$ & 100 \\
\hline $2017-2018$ & 100.78 \\
\hline $2018-2019$ & 134.37 \\
\hline
\end{tabular}

\section{Trend Analysis on Sales}

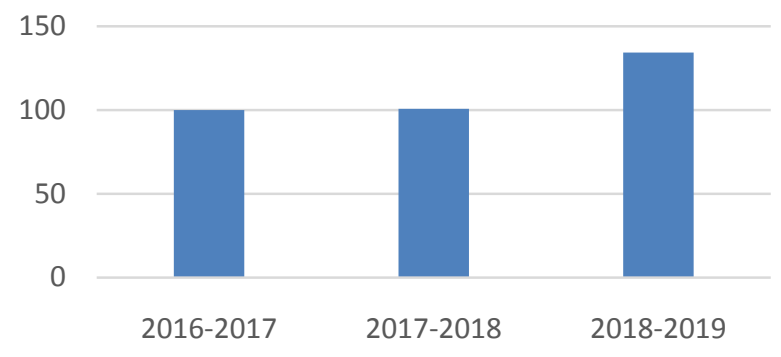

\section{Interpretation}

The above table shows the trend analysis on sales for the period of three years. It was 100 in the year of 2016-2017 and it will be increased to 100.78 during the year of 2017-2018. In the year of $2018-2019$ the ratio is 134.37 and its is rapidly increased it indicates the onset of changes in the near term revenue growth rates of a business.

\section{Trend Analysis on Current Asset}

Trend Analysis provides a means to analyze company data over a period of time by focusing on the change in specific line items within the income statement and balance sheet .changes are typically measured in dollars and percentages

\begin{tabular}{|c|c|}
\hline $\begin{array}{llll} & \text { e } & \text { a } & \text { r }\end{array}$ & Ratio \\
\hline $2016-2017$ & 100 \\
\hline $2017-2018$ & $6 \quad 6$ \\
\hline $2018-2019$ & 7 \\
\hline
\end{tabular}

\section{Trend Analysis on Current Asset}

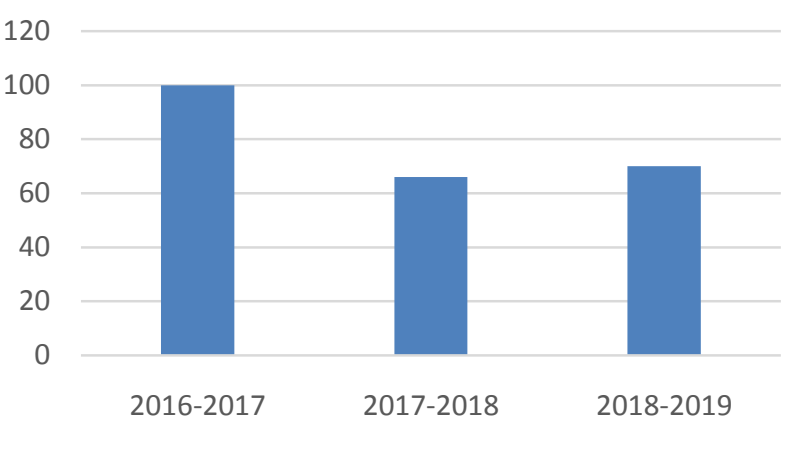

\section{Interpretation}

The above table shows the trend analysis on current asset for the period of three years. It was 100 in the year of 2016-2017 and it will be decreased to 66 in the year of 2017-2018. In the year of 2018-2019 is 70 rapidly increased and its shows that company's liquidity or ability to pay off short term debts.

\section{CONCLUSION}

The study conducted on ratio analysis at " Etexpro Inde" gives a view if analysis evaluation of liquidity position of the company. Based on the tools used analysis and interpretation have been made giving way for useful and constructive suggestions. Thus the ratio analysis of the company is not satisfactory. The company should enhance its performance for meeting challenges and exploiting opportunities in future. The project will guide to the management to interpret its weakness and problems this will certainly help the management to taking financial decision. However more efforts need to be improve the financial position for the growth of the company.

\section{REFERENCES}

[1] Agarwal N.P., "Analysis of Financial Statements"- National Publishing House, 23 Darya Ganj, New Delhi , 1981

[2] Choudhary B. Roy, "Working Capital Management" Eastern Law House, Calcutta, 1977.

[3] Dobrovolsky S.P., "The Economics of Corporate Finance" -Tata Mcgrew Hill, New Delhi, 1976.

[4] Fregmen J.M., "Accounting for Managerial Analysis" Homewood, Irwin, 1972.

[5] Ghosh P.K. and Gupta S.C., "Fundamental of Management Accounting" - National Publishing House, New Delhi, 2nd Ed., 1979.

[6] GitmanL.J.,Harper and Row, "Principles of Managerial Finance" - New York, 1979.

[7] Gupta L.C., "Corporate Management and Accountability towards a Joint Sector - Macmillan, Madras, 1974.

[8] Lav.B., "Financial Statement Analysis - A New Approach" - Englewood, Cliffs, Prentice Hall, 1974.

[9] Bright M.G., "Financial Management"- Tata Mcgrew Hill Publishing Compay Ltd., New Delhi, 1978. 
[10] Kulkarni P.V., "Financial Management -A Conceptual Approach" - Himalaya Publishing House, Bombay, 2nd Edn., 1983.

[11] Pandey I.M., "Financial Management" - Vikas Publishing House, New Delhi, $\neg 1$ st Edn., 1979.

[12] Robort W. Hohnson., "Financial Management" - Allyn\& Bacon Inc. Boston 4 thEdn. 1977.

[13] Vanhorne J.C., "Financial Management" - Prentice Hall ,Englewood, $\neg$ Cliffs, New Delhi, 1974.

[14] ViscioneJ.A ., "Financial Analysis : Principles and Procedures" - Boston $\neg$ Houghton Miffin, 1977.

[15] Wright L.T., "Financial Management : Analytical Techniques” - Columbus, Ohio, Orid, 1974.

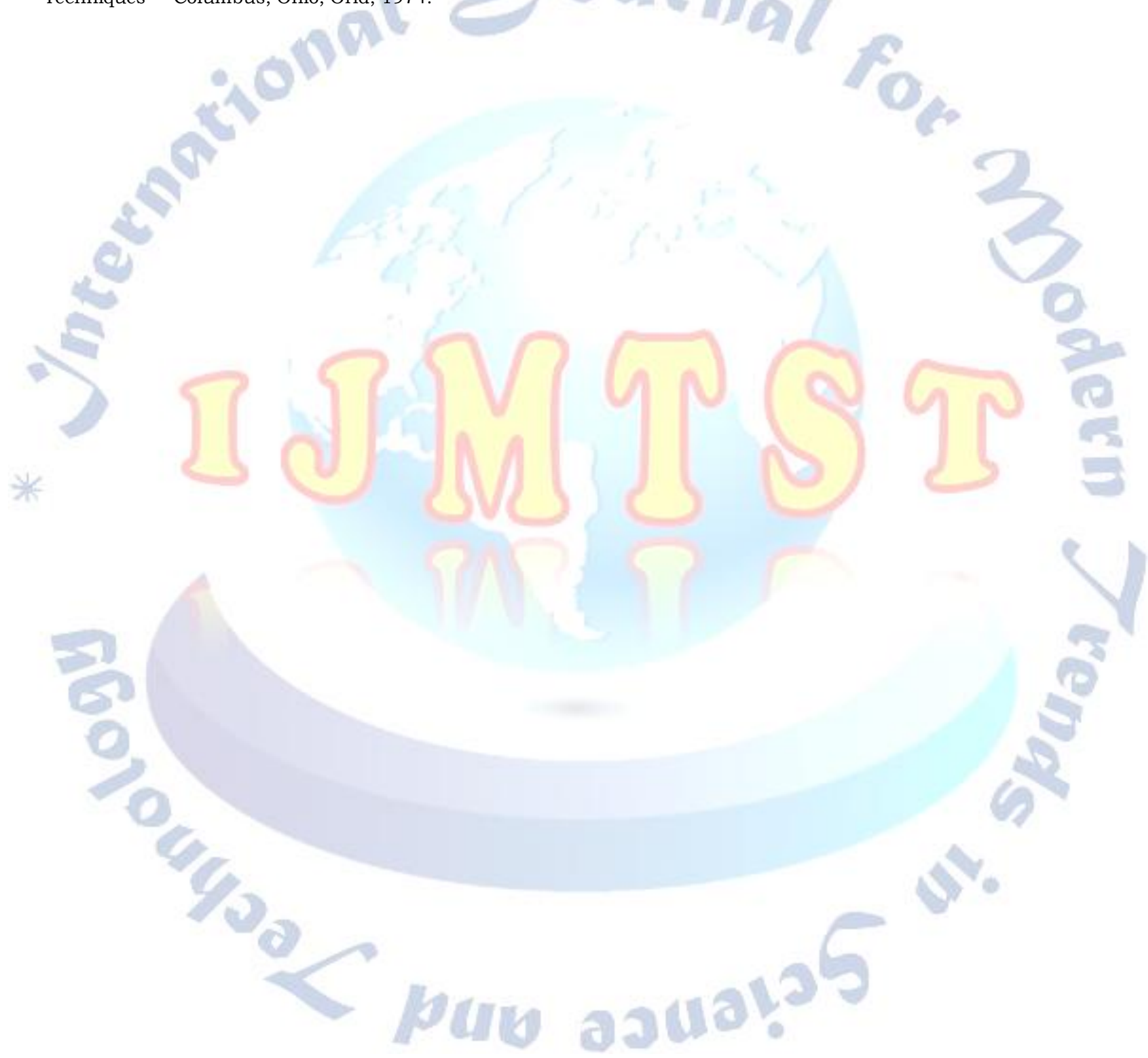

